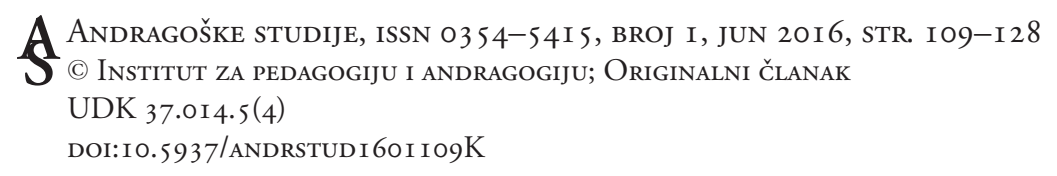

Tinie Kardol ${ }^{1}$

Vrije Universiteit Brussel/ Vughterstede, Belgium

Alina Vlădut ${ }^{2}$, Sorin Avrim ${ }^{3}$

University of Craiova, Romania

\title{
Intergenerational Learning and Social Inclusion: Measuring the Impact in Five European countries ${ }^{4}$
}

\begin{abstract}
European citizens still risk social exclusion. According to recent figures the rate of social exclusion differs per country and per target group. Based on recent societal developments (like the increase in youth unemployment and ageing population), it seems necessary to ensure that the increasing number of older people in Europe can actively be involved in European society, in addition to supporting youngsters in order to increase their social inclusion. Although several studies showed that education can increase social inclusion among learners, evidence is still lacking on whether intergenerational learning for youngsters and older people can increase social inclusion for these both groups. Generations Using Training for Social inclusion (GUTS) is a European project measuring the impact of intergenerational learning on social inclusion. One of the main
\end{abstract}

\footnotetext{
${ }^{1}$ Tinie Kardol, PhD is Professor of Active Ageing at the Faculty of Psychology and Educational Sciences, Vrije Universiteit Brussel, Belgium (mjmkardol@hotmail.com).

2 Alina Vlădut, PhD is Lecturer at the Faculty of Social Sciences, University of Craiova, Romania (vladut_alina2005@yahoo.com).

${ }^{3}$ Sorin Avrim is Teaching Assistant at the Faculty of Social Sciences, University of Craiova, Romania (avram_ sorin@central.ucv.ro).

4 The paper was written through the collaboration of the group of authors: Liesbeth De Donder, Vrije Universiteit Brussel; Radu Constantinescu, University of Craiova; Titela Vilceanu, University of Craiova; Dorien Brosens, Vrije Universiteit Brussel; Maurice De Greef, Vrije Universiteit Brussel; Daniela Grignoli, University of Molise; Margherita di Paolo, University of Molise; Regy van den Brand, Vughterstede Dis Kusters, Vughterstede; Dieter Zisenis, bbb Büro for berufliche Bildungsplanung R. Klein \& Partner GbR; Rosemarie Klein, bbb Büro for berufliche Bildungsplanung R. Klein \& Partner GbR; Anamarija Tkalcec, CESI Center for Education and Research; Sanja Cesar, CESI Center for Education and Research; Liesbeth Goossens, CVO Antwerpen; Koen Daenen, CVO Antwerpen; Ilze Buligina, Talakizglitibas biedriba; Biruta Sloka, University of Latvia; Petra Herre, Evangelisches Erwachsenenbildungswerk Nordrhein.

This paper is part of the GUTS-project, co-funded by the European Commission's Erasmus+ program. This publication [communication] reflects the views only of the authors, and the Commission cannot be held responsible for any use which may be made of the information contained therein.
} 
goals of the GUTS project was to combine the strengths of older people and youngsters so that they can learn from each other and increase their skills in order to face daily problems in society. In line with the Europe 2020 Strategy GUTS aimed to decrease social exclusion via intergenerational learning projects. Ten learning areas (LA) were organized in five countries, namely: Belgium, Croatia, Germany, Latvia and The Netherlands. The results indicate that the intergenerational learning areas of the GUTS project stimulated the experienced increase in social inclusion of learners of both generations and that elements of the learning environment seem to influence this increase. More research is needed to explore the specific influence of these elements on both target groups older people and youngsters.

Keywords: intergenerational learning, active ageing, social inclusion, impact of learning, European learning areas.

\section{Introduction}

According to Eurostat (2014a) 24.4\% of the European citizens still risk social exclusion. According to recent figures of Eurostat (2014a) the rate of social exclusion differs per country and per target group. For example countries like Croatia, Italy, Latvia and Romania seem to have more citizens risking social exclusion than the European average. On the other hand in Belgium, Germany and The Netherlands fewer citizens seem to experience social exclusion (Eurostat, 2014a). Still a significant share of the European population experience problems in daily life and cannot fully participate in society. Therefore the European Commission (2010) would like to invest time and resources in order to lift up 20 million people out of the risk of social inclusion by 2020. According to recent figures there are especially two target groups who seem to experience different problems in order to participate in society, namely youngsters and older people.

In addition to risking social inclusion, youngsters also seem to experience difficulties in getting a job. Youth unemployment still seems to be an enormous problem in several European countries. For example in countries like Belgium, Latvia and Romania almost 25\% of the youngsters between 16 and 24 years old seem to be unemployed (Eurostat 2014b). But even more striking are the figures from countries like Croatia and Italy where $40 \%$ up to $50 \%$ of the youngsters between ages of 16 and 24 seem to be unemployed. In addition to the risk of social exclusion they seem to experience problems on the labour market. Therefore their position in daily life can be problematic when they need to develop themselves as young citizen of Europe.

Secondly, it seems to be difficult for older people to join activities in society. For example the Belgian Ageing Studies investigated the needs of circa 70,000 
older people and evidenced that especially older people above 80 years are more confronted with social exclusion (Verté and De Witte, 2015). According to Eurostat $(2014 \mathrm{c})$ the ageing population will increase in the upcoming years. This becomes clear by the "projected old age dependency ratio", which shows that within about 70 years range, it is estimated that the old age dependency ratio will on average double in EU countries (Eurostat, 2014c). Therefore it seems necessary that an increasing number of older people in Europe can actively be involved in European society in addition to supporting youngsters in order to increase their social inclusion to ensure.

According to De Greef, Segers and Verté (2012), continuing education can increase social inclusion among (young) adult learners. If one joins a learning process, then most of the learners experience a better social inclusion in daily life (De Greef, Segers and Verté, 2012). For example one is less isolated, joins voluntary work, joins activities in the neighbourhood, gets better language skills or is more assertive. Also Kumpalainen (2010a) seems to underline the importance of education in order to increase the rate of social inclusion. According to Kumpalainen (2010a) systems of education can be supportive of individual growth in citizenship. In other words education can play an important role in increasing quality of life (Kumpalainen, 2010b).

Although several studies showed that education can increase social inclusion among learners evidence is still lacking on whether education for youngsters and older people can increase social inclusion for these both groups. In other words is it possible that a learning environment in which next to youngsters older people also learn new knowledge, skills and attitudes, both groups experience an increase in their social inclusion? This study focuses on the results of this intergenerational learning process on social inclusion. Based on ten realised learning areas in five countries, the question has been raised if intergenerational learning can increase the rate of social inclusion of both youngsters and older people.

\section{Intergenerational learning in Europe by the GUTS project}

Generations Using Training for Social inclusion (GUTS) is a European project measuring the impact of intergenerational learning on social inclusion. One of the main goals of the GUTS project was to combine the strengths of older people and youngsters so that they can learn from each other and increase their skills in order to face daily problems in society. GUTS situates itself in the context of a greater life expectancy at European level and the consequent increase in the need for active ageing, as well as of a greater separation among generations, especially 
younger and older people. Intergenerational and cultural learning aims to facilitate contacts and build communication bridges. Older people can acquire new paths of knowledge and will try to upgrade their skills in order to increase their social inclusion, while younger people will develop key competences in order to orient themselves and acquire a position in the labour market. In line with the Europe 2020 Strategy GUTS aimed to decrease social exclusion via intergenerational learning projects. Ten learning areas (LA) were organized in five countries, to mention: Belgium, Croatia, Germany, Latvia and The Netherlands.

\section{Belgium}

\section{LA 1: Multimedia lessons for seniors}

This LA was based on the finding that older people often own a device like a smartphone or a tablet, but do not always know how to use it. Young adults on the other hand have already acquired a lot of knowledge on the function of smart phones, tablets and laptops. The three most important results were: (1) seniors received a clear answer to their practical questions and feedback on their skills of handling a technological device; (2) young adults improved their informal teaching skills; (3) seniors and young adults interacted and there was an exchange of knowledge between the generations, as well as within the generations.

\section{LA 2: Stop motion animation and etching}

A group of older and younger people created a stop motion animation movie and etching. All the learners worked together in a bottom-up creative process in order to obtain shared creative results. The three most important results obtained were: (1) learners got the chance to interact in an informal way and exchange skills and knowledge; (2) learners had ownership of their creative process; (3) at the end of the workshop, all the learners obtained a concrete, creative result.

\section{Croatia}

\section{LA 1: Women talks: What do we want our society to look like?}

\section{LA 2: Sharing history and experiences}

These learning areas involved methods for innovative and creative learning processes on intergenerational work and brought together 37 young and old women to express their personal reflections and views on actual problems caused by neoconservatism, recent war, economic crisis and discrimination. The three most 
important results obtained were: (1) sharing the knowledge and experiences between young and older women about life and society they live in; (2) raising awareness in both generations on needs, strengths, weaknesses, capacities and bringing them together to learn about each other; (3) statements collected to form the Platform for the action: What do we want our society to look like?

\section{Germany}

\section{LA 1: Being outside}

This learning area focused on the development of effective and successful participation processes to involve youth and younger adults on the one hand and the eldest amongst the old on the other hand. During the learning process they aimed to organise common activities using the public spaces in the neighbourhood where both groups live, and to create attractive and joyful learning environments outside formal education. The project is to be supported through different artistic approaches (visual arts). The three most important results obtained were: the "Regenbogenhaus" and their residents are more widely known as a part of the neighbourhood; (2) the contact between older and younger adults received a more obvious character; (3) intergenerational learning couldn't be organized in a standardized way with a fixed curriculum and / or course format but needs a structure offering opportunities for encountering and joint activities.

\section{LA 2: Quartier 117: Learning programme for the 'New community of Generations and Cultures in the Neighbourhood'}

The basic concept of this learning area has been developed in co-operation with specialists from educational and social work and the housing industry, artists, as well as a large number of volunteers from various professional fields. The three most important results obtained were: (1) creating the awareness of being a community despite being highly heterogeneous; (2) integration of refugees in existing groups; (3) developing a low level orientation programme for refugees.

\section{Latvia}

\section{LA 1: Latvian Folk Tradition Group "BUDELI"}

The project prepared the learners of the folk group BUDELI for the Latvian

Christmas traditions. They learned new and repeated games, songs, beliefs and 
customs from previous year. The three most important results obtained were: (1) satisfaction with the fact that the learners learned / repeated Latvian traditional Christmas songs, games and customs; (2) through our presence in the Latvian winter solstice, we received the blessing of the people who attended, watched, and simply stayed home; (3) we delighted children with games and songs.

\section{LA 2: Advancement}

The learning took place in an informal environment by using discussions, practical examples and role play focussing on improvement of social skills. During the existence of the learning area the learners worked in teams from different ages and socio-cultural backgrounds, in order to solve common problems and agreeing on optimal solutions. The three most important results obtained were: (1) the self-confidence of the learners has grown; (2) the learners feel more at ease among people of different age and background; (3) the learners discovered that they enjoy communication, learning and sharing.

\section{The Netherlands}

\section{LA 1: Ipad-lessons Vughterstede}

In this learning area young people gave iPad lessons to older people. A youngster (14-21 years) and an older person (79-88 years) formed a solid couple. The lessons occurred weekly in a room at the local nursing home, or at the home of the older person. The three most important results obtained were: (1) the youngsters and older people enhanced their social contacts and their exchange of knowledge; (2) the youngsters also increased their possibilities in the labour market; (3) the youngsters also increased their enthusiasm to start a vocational training.

\section{LA 2: Work experience placement}

The project 'Work experience placements' has been established in cooperation with the municipality of Vught. Learners with a great distance to the labour market have been asked to join the project. These learners were offered a work experience in order to increase their chances of a paid job in the labour market. These, mostly younger learners were linked to older experienced workers in order to guide them during their work at Vughterstede. The three most important results obtained were: (1) several learners showed a positive development in learning a normal daily routine, manners (e.g. treatment of clients and colleagues with respect) and competencies to increase the chances of employment; (2) in most cases 
there was a good match between the employee with a work experience placement and the employee of Vughterstede; (3) the generational difference (gap) between the employee with a work experience placement and employee of Vughterstede was perceived as positive.

\section{Research questions}

This paper aims to examine whether the ten different learning areas have an impact on the social inclusion of the involved learners. Besides this, the goal is to examine which elements of the learning areas influenced the possible increase of social inclusion. Furthermore the GUTS consortium would like to explore how the involved tutors / trainers perceived the process of intergenerational learning realised in the ten different learning areas. Therefore the following research questions have been formulated:

1. How many learners (youngsters and older people) experience an increase in which element of social inclusion?

2. Which elements of the learning area seem to influence the increase in social inclusion among the involved learners (youngsters and older people)?

3. What is the perception of the concept of intergenerational learning of the involved teachers after providing guidance in different learning areas?

\section{Research methodology}

\section{Data collection and respondents}

At the beginning and the end of life of the learning area, the learners have been asked to fill in a quantitative questionnaire concerning social inclusion. Each learner received an oral and written instruction explaining the standardized procedure in order to fill in the questionnaires. 117 persons participated in the learning activities and filled in the questionnaire at both times: 24 in Belgium, 19 in Croatia, 9 in Germany, 38 in Latvia and 27 in The Netherlands.

$68.4 \%$ of the learners were females, mainly due to the fact that some learning areas exclusively addressed them (e.g. in Croatia) and $17.9 \%$ of the learners were immigrants, due to the same reason (e.g. in Germany). The char- 
acter of the intergenerational project is evidenced by the fact that the age structure is well balanced: the share of the groups 0/25 years old, 26/45 years old, $46 / 65$ years old and $66 / 100$ years old being of about $25 \%$. Regarding the civil status of the learners the data indicate that about $40 \%$ of the learners were married, $46 \%$ were single, $3.4 \%$ declared they lived with a partner and 9.5 were widowed.

$27.6 \%$ were secondary school graduates. Over $20 \%$ of the learners were graduates of higher education institutions, $12.1 \%$ were graduates of vocational education and $6 \%$ graduated only of primary school. The longest duration spent in the educational system (including kindergarten) was of $11-15$ years (46.6\%), followed by $16-20$ years with a share of $23.3 \%, 6-10$ years with $18.1 \%$ and less than 5 years with $10.3 \%$.

$52 \%$ did not work being either retired (31\%) or unemployed (21\%). $36 \%$ had paid work. $12 \%$ of the learners were only involved in volunteering activities.

The motivation to participate in the activities within the project was mainly personal (48.2\%). 15.5\% participated because they were sent by an official institution (e.g. municipality), $11.8 \%$ were encouraged by family to attend, and $3.6 \%$ were sent by their employer or colleagues. Finally $20 \%$ indicated to have other reasons.

Personal motivation to participate in intergenerational, cultural learning activities, approximately $50 \%$ of all the learners, supports such an initiative as important for community members. The interest of organizations in such activities is highlighted by the $16 \%$ of the learners that were encouraged to participate by such institutions.

\section{Measurement instruments}

The research used 2 standardised questionnaires:

1. One for learners at the beginning and the end of the duration of the learning area

2. One for tutors / trainers at the end of the learning area duration

Firstly, the questionnaire for the learners included personal characteristics: e.g. age, gender, marital status, educational level. In order to measure social inclusion the SIT-instrument (Social Inclusion after Transfer) of De Greef, Segers and Verté (2010) has been used. Table 1 provides an overview of the variables used (including number of items, example items and Cronbach's Alpha's). 
Table 1: Cronbach's Alpha values for the questionnaires applied to learners

\begin{tabular}{l|c|l|c}
\hline \multicolumn{1}{c|}{ Variable } & $\begin{array}{c}\text { Nr. of } \\
\text { items }\end{array}$ & \multicolumn{1}{|c}{ Example of statement } & $\begin{array}{c}\text { Cronbach's } \\
\text { Alpha }\end{array}$ \\
\hline Influencing factors of training design & & 0.924 \\
\hline Support teacher & 8 & $\begin{array}{l}\text { I felt appreciated by my tutor for participating } \\
\text { in the course }\end{array}$ & 0.785 \\
\begin{tabular}{l|l} 
Learning contents \\
and -activities
\end{tabular} & 4 & $\begin{array}{l}\text { During the course there were practical } \\
\text { demonstrations of problem solving }\end{array}$ & 0.640 \\
Direct surroundings & 9 & $\begin{array}{l}\text { Since completing the course people around } \\
\text { me notice when I do not use my new skills or } \\
\text { knowledge }\end{array}$ & $\begin{array}{l}\text { Since completing the course people around me } \\
\text { think joining a course is very worthy }\end{array}$ \\
Transfer possibilities & 3 & $\begin{array}{l}\text { I am retired/ I am unemployed } \\
\text { I am happy with my life }\end{array}$ & $-0.116^{*}$ \\
Upbringing and work & 3 & $0.357^{*}$ \\
\hline
\end{tabular}

Social inclusion (dimensions)

\begin{tabular}{l|c|l|c}
\hline Digital skills & 3 & I can use the internet & 0.943 \\
$\begin{array}{l}\text { Assertiveness } \\
\begin{array}{l}\text { Intergenerational } \\
\text { competency }\end{array}\end{array}$ & 5 & $\begin{array}{l}\text { I am a confident decision maker } \\
\text { I have good interaction skills with people in my } \\
\text { generation }\end{array}$ & 0.972 \\
$\begin{array}{l}\text { Meeting and } \\
\text { attempting }\end{array}$ & 5 & I meet plenty of people of different generations & 0.893 \\
$\begin{array}{l}\text { Private contacts } \\
\begin{array}{l}\text { Nature and sports } \\
\text { Arts and culture }\end{array}\end{array}$ & 4 & $\begin{array}{l}\text { I join sport activities } \\
\text { I join artistic activities (theatre, movies, } \\
\text { painting, craftsmanship, music, dancing and } \\
\text { singing) }\end{array}$ & 0.761 \\
\hline
\end{tabular}

* This value is too low and this scale is excluded from further analysis 
Furthermore the tutors / trainers have been asked to fill in a questionnaire afterwards focusing on their vision on intergenerational activities, namely:

- Perception of intergenerational activities

- Main barriers in intergenerational communication

- Efficiency of co-creative intergenerational activities for specified groups and learning areas

- Competencies of the specific organised learning area

- Efficiency of learning approaches during intergenerational learning

- Usefulness of criteria of co-creative space during intergenerational learning

- Desirable changes concerning organised learning area

\section{Data analysis}

The analysis of the quantitative results has been conducted in SPSS. After entering the data, several steps were undertaken. Firstly, the reliability of the scales has been checked by calculating the Cronbach's Alpha coefficients for the considered variables for the questionnaires applied to the learners (see table 1). The analysis emphasized excellent values in terms of the statistical reliability of the questionnaire for the following questions regarding the "support teacher", "digital skills" and "intergenerational competency". Other variables like "assertiveness" and "meeting and attempting" also registered a good score (between 0.8 and 0.9) involving direct answers to the respondents' ability to interact with each other and the trust that they have in their own actions. Acceptable results were registered in case of the variables "learning contents and activities", "direct surroundings", "transfer possibilities", "arts and culture", all with Cronbach's Alpha's above 0.60 . Less conclusive results from the point of view of statistical reliability were registered by the following variables: "upbringing and work", "nature and sports" and "care". Consequently, these variables are excluded from further analysis.

Secondly, in order to calculate the perceived increase in the social inclusion variables change-variables have been calculated as the scores on the post-test minus the scores on the pre-test. Thirdly, by conducting a non-parametric correlation analysis by means of Mann-Whitney tests followed by a logistical regression analysis, the influence of the elements of the learning area on the perceived increase of social inclusion has been discerned. Finally, descriptive statistics were 
used to describe the perception of the tutors / trainers on the concept of intergenerational learning and the perception of the learning activity itself of the tutors / trainers.

\section{Results}

1. How many learners (youngsters and older people) experience an increase in which element of social inclusion?

Figure 1 gives an overview of the percentage of the learners experiencing an increase of social inclusion. Firstly, the variable "digital skills" explains the learner's skills related to the utilisation of the computer and the Internet. Most of the learners used computers mainly to get information and to communicate. In case of this variable, $25.2 \%$ of the learners experienced an increase in their digital skills at the end of the learning activity.

Secondly, the variable "assertiveness" registered the highest values with regard to the impact of the participation in the learning activities: $48.3 \%$ of the learners gave higher scores to the questions related to this variable. There was an increase in personal trust, ability to manage and solve conflicts, ability to solve problems and trust in personal capacity to make decisions.

With regard to "intergenerational skills", there was an increase among $29.3 \%$ of the learners.

The interaction between the learners and the natural and social environment was evaluated by the variable "meeting $\&$ attempting". $29.9 \%$ of learners noted an increase in scores after attending the learning activities. This increase actually refers to a perceived increase of the participation in activities outside the house, meeting people of the same or different generations, a greater number of acquaintances or new friendships.

Furthermore the relationship with family and close friends was also evaluated by the variable "private contacts", for which $23.1 \%$ of the respondents rated higher scores on the post-test questionnaire at this variable. This means that these learners registered increases in the number of visits to the family, friends and in the satisfaction degree with regard to their relationship.

Finally, as concerns the last variable "arts \& culture" aimed at measuring the impact on practice / participation in cultural activities (like theatre, film, painting, music, dance): $22.4 \%$ learners participated more in such activities after the learning area. 


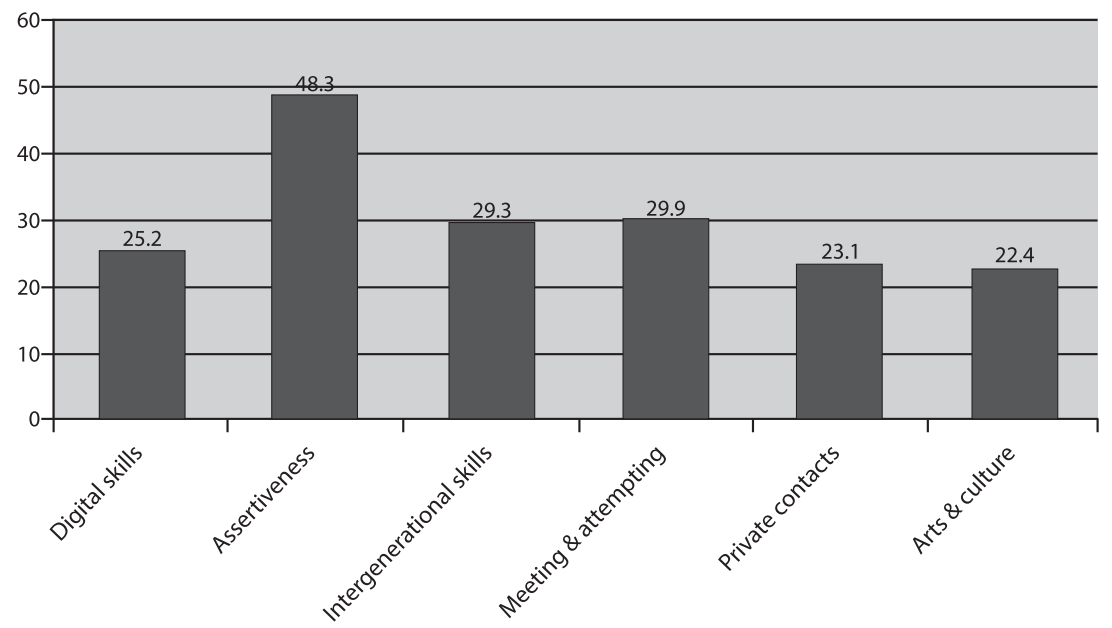

Figure 1: Share of the increase of social inclusion dimensions between baseline and follow-up

2. Which elements of the learning area seem to influence the increase on social inclusion among the involved learners (youngsters and older people)?

In the first phase we calculated bivariate relations. The analysis of the influence of the considered learning environments on the results of the aforementioned variables has been achieved by conducting a non-parametric correlation analysis by means of Mann-Whitney tests. According to table 2 it has been found that there is a significant correlation between "teacher support" and two dimensions of social inclusion, namely "meeting \& attempting" $(U=845,500 ; p=0.002)$ and "private contacts" $(\mathrm{U}=746,500 ; \mathrm{p}=0.024)$, between "transfer possibilities" and "meeting and attempting" $(\mathrm{U}=781,500 ; \mathrm{p}=0.009$ and between "learning contents and -activities" and "assertiveness" ( $\mathrm{U}=1179 ; \mathrm{p}=0.046)$.

Table 2: Significance levels of bivariate analyses between training design characteristics and increase in social inclusion

\begin{tabular}{l|l|l|l|l}
\hline Training design characteristics $\rightarrow$ & $\begin{array}{l}\text { Teacher } \\
\text { support }\end{array}$ & $\begin{array}{l}\text { Learning } \\
\text { contents and } \\
\text {-activities }\end{array}$ & $\begin{array}{l}\text { Direct } \\
\text { surroundings }\end{array}$ & $\begin{array}{l}\text { Transfer } \\
\text { possibilities }\end{array}$ \\
\hline Increase in social inclusion per variable $\downarrow$ & 0.613 & 0.776 & 0.246 & 0.456 \\
\hline Increase in digital skills & 0.610 & $0.046^{*}$ & 0.170 & 0.144 \\
Increase in assertiveness & 0.194 & 0.583 & 0.241 & 0.961 \\
Increase in intergenerational skills & & &
\end{tabular}




\begin{tabular}{|c|c|c|c|c|}
\hline Training design characteristics $\rightarrow$ & \multirow{2}{*}{$\begin{array}{l}\text { Teacher } \\
\text { support }\end{array}$} & \multirow{2}{*}{$\begin{array}{l}\text { Learning } \\
\text { contents and } \\
\text {-activities }\end{array}$} & \multirow{2}{*}{$\begin{array}{l}\text { Direct } \\
\text { surroundings }\end{array}$} & \multirow{2}{*}{$\begin{array}{l}\text { Transfer } \\
\text { possibilities }\end{array}$} \\
\hline Increase in social inclusion per variable $\downarrow$ & & & & \\
\hline Increase in meeting $\&$ attempting & $0.002^{* *}$ & 0.773 & 0.053 & $0.009^{* *}$ \\
\hline Increase in private contacts & $0.024^{*}$ & 0.977 & 0.948 & 0.144 \\
\hline Increase in arts \& culture & 0.617 & 0.355 & 0.639 & 0.820 \\
\hline
\end{tabular}

*: Correlation is significant at the 0.05 level (2-tailed).

**: Correlation is significant at the 0.01 level (2-tailed).

In a second phase the significant variables were included in a logistic regression analysis with increase of social inclusion as a dependent variable. Table 3 shows the results of this logistical regression analysis and indicates that "teacher support" is a significant predictor for two variables of social inclusion, namely "meeting \& attempting" (-0.320) and "private contacts" (-0.201). Learning contents and activities, and transfer possibilities were not significant.

Table 3: Logistic regression results with social inclusion variables of as dependent variables

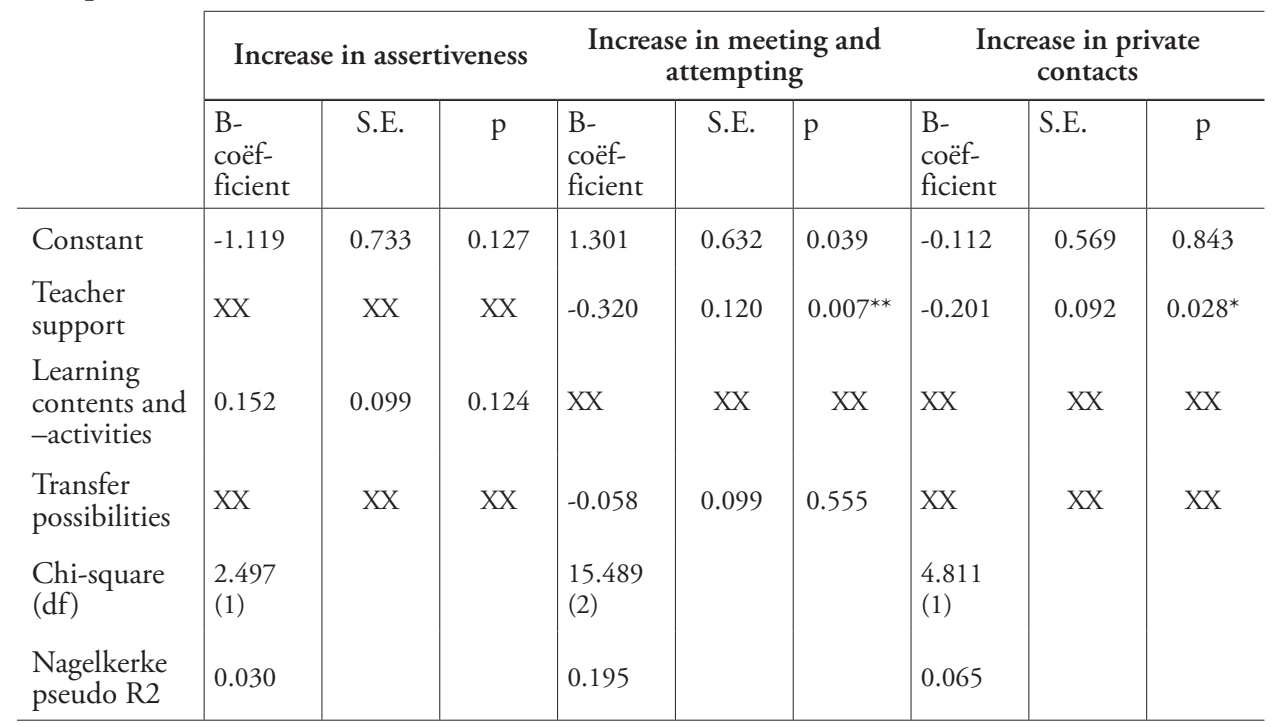

$X X=$ not included in the logistic regression because not significant on bivariate level

*: significant at the 0.05 level

**: significant at the 0.01 level 
3. What is the perception of the concept of intergenerational learning of the involved teachers after providing guidance in different learning areas?

The evaluation of the development and achievement of the learning areas was done based on the tutors / trainers' perception. With regard to the intergenerational activities, we asked them about several components focusing on their vision on intergenerational activities.

Firstly, according to table 4 the tutors / trainers' perception on the activities is predominantly focused on learning activities with the goal of social inclusion, this aspect registering the highest average of 7.83 on a scale out of 10 . At the opposite end, the lowest score was obtained by the perception of the learning activities without aiming at social inclusion (4.64 on a scale out of 10).

Secondly, the main intergenerational barriers are represented by the differences between generations, according to the highest score of 6.67 on a scale out of 10 (see table 4). The next barrier, according to tutors / trainers, is related to digital skills (6.58 on a scale out of 10). The last two positions are held by the low level of awareness regarding intercultural differences ( 4.18 on a scale out of 10) and illiteracy ( 3.55 on a scale out of 10 ).

Thirdly, table 4 shows that the tutors / trainers consider that the highest efficiency of co-creative intergenerational activities for different demographic groups is registered in case of the group of the oldest old and young adults (6.91 on a scale out of 10). The next group that is considered to be opportune for developing intergenerational activities is that of grandparents and grandchildren (6.83 on a scale out of 10$)$.

Fourthly, with regard to the development of intergenerational activities it seems that tutors / trainers consider that learning or improving a language is the most appropriate activity ( 7.17 on a scale out of 10$)$. The next score of 6.82 on a scale out of 10 was indicated by tutors / trainers for ICT. Lifestyle (6.64 on a scale out of 10) and family topics (6.58 on a scale out of 10) obtained third and fourth place (see table 4).

Table 4: Tutors / trainers perceptions on intergenerational learning

\begin{tabular}{ll}
\hline Questions for tutors / trainers & Mean score \\
\hline \hline 1. How do you see intergenerational activities? & \\
\hline Communication activities (without learning aims) & 6.73 \\
\hline Formal activities, with specific learning outcomes & 5.27 \\
\hline Activities inside family mainly & 5.67 \\
\hline
\end{tabular}




\begin{tabular}{|c|c|}
\hline Questions for tutors / trainers & Mean score \\
\hline Learning activities without social inclusion aims & 4.64 \\
\hline Learning activities with social inclusion aims & 7.83 \\
\hline \multicolumn{2}{|c|}{ 2. What are the main barriers in intergenerational communication? } \\
\hline Generation gap & 6.67 \\
\hline Illiteracy & 3.55 \\
\hline Digital skills & 6.58 \\
\hline Less developed intercultural awareness & 4.18 \\
\hline Other particular factors (please specify): & Too less $\mathrm{N}$ \\
\hline \multicolumn{2}{|c|}{$\begin{array}{l}\text { 3. How do you rate the efficiency of co-creative intergenerational } \\
\text { activities for the following groups? }\end{array}$} \\
\hline Grandparents and grandchildren & 6.83 \\
\hline Older (still active) and younger professionals & 6.55 \\
\hline Oldest old and young adults & 6.91 \\
\hline $\begin{array}{l}\text { 'Old' (integrated) migrants (first generation) and 'new' } \\
\text { migrants (second or third generation) }\end{array}$ & 6.55 \\
\hline Other groups. Please specify: & Too less $\mathrm{N}$ \\
\hline \multicolumn{2}{|c|}{$\begin{array}{l}\text { 4. How do you rate the efficiency of co-creative intergenerational } \\
\text { activities for the following learning areas? }\end{array}$} \\
\hline Gender issues & 5.36 \\
\hline Family & 6.58 \\
\hline Lifestyle & 6.64 \\
\hline Scientific education & 5.08 \\
\hline ICT education & 6.82 \\
\hline Language skills & 7.17 \\
\hline Intercultural awareness & 6.08 \\
\hline Vocational training & 6.00 \\
\hline Entrepreneurship & 4.91 \\
\hline Other areas. Please, specify: & Too less $\mathrm{N}$ \\
\hline
\end{tabular}

Finally tutors / trainers have been asked what they would change in intergenerational activities developed within the realised learning area. Tutors / train- 
ers gave the highest score to strategy (5.17 on a scale out of 10$)$. This means that they consider the development of the activities together with the learners according to a more rigorous planning as important. The elaboration of an advertising strategy, implementation, teaching methods, and teaching resources are just some examples of things that should be developed more before the start of the activities. In fact, the second component recommended by tutors / trainers to be improved is also related to strategy / planning and it refers to establishing clearer goals in terms of learners' skills before and after the activities.

\section{Conclusions and discussion}

According to the results of the analysis it became clear that a half of group the learners (22.4\% to $48.3 \%$ ) experienced an increase in several dimensions of social inclusion and especially in assertiveness, meeting \& attempting and intergenerational skills. This means that these learners point out that they are more assertive, meet more and other people and have a better contact with people of their own and the other generation after joining the learning area. Furthermore it seems to be the case that teacher support is the only element of the learning environment that seems to influence this increase. More detailed due to the support of the teacher learners meet more and other people and visit their family and friends more often and are more satisfied about these contacts.

Besides the perceptions of the learners the tutors / trainers support these results due to the fact that most of them perceive intergenerational activities to be important in order to stimulate increase of social inclusion in addition to the improvement of communication. Most difficult to reach this, according to the tutors / trainers, is the gap between generations and the lack of digital skills. Finally tutors / trainers would like to improve the strategy used during the learning area in order to get better results.

Although it seems to be difficult to compare these results with other studies due to the fact that research concerning the impact of intergenerational learning in Europe is lacking, the results of the GUTS project are comparable with other European studies. For example the cross-cultural study of the EDAM project (Education Against Marginalisation) shows that between 20.2\% and 44.2\% of the adult learners seems to experience an increase of social inclusion on several variables of social inclusion (Lupi et al., 2011). According to the results of the study of the learning areas of the GUTS project the results are comparable (and even a little bit higher). This confirms the results of the earlier study of Lupi et al. (2011) that education indeed can increase the experienced rate of social inclusion 
among vulnerable groups in European society. In other words the statement of Kumpalainen (2010b) that education can play an important role in increasing quality of life can be confirmed for a significant share of the learners in the learning areas of the GUTS project.

These results are supportive of the European goals of ET2020 and the European goals of the Renewed Agenda for Adult Learning. The GUTS project has focused on developing, testing and implementing ten innovative, intergenerational and cultural learning areas in order to increase social inclusion among youngsters and older people. These learning areas have been developed by the innovative methodology of co-creation between older people and youngsters. During this intergenerational and cultural learning process, youngsters have provided older people with modern knowledge and tried to upgrade their skills in order to increase the social inclusion of these older people. On the other hand the older people have stimulated the youngsters to develop their key competences in order to increase their social inclusion in addition to their opportunities in the labour market. More concretely, this innovative learning process has attracted more youngsters (and older people) to join education and training in order to acquire better key competencies fitting the goals of ET2020. According to the contents of these learning areas it became clear that it should be flexible and fitting into the local context of the learners (serving the goals of the Renewed Agenda for Adult Learning).

Some important matters still have to be taken into account in order to interpret the results of this study. Firstly, it would be interesting to conduct a qualitative analysis in order to explore the meaning of the different dimensions of social inclusion. For example what does it mean for the learners that they meet more and other people or that they are more assertive? Besides this, it would be interesting to explore what influences of the learning environment specifically contribute to this result? According to the results of the analysis it would be interesting to know why and how the support of the teacher influences the increase of several dimensions of social inclusion.

Secondly, this study neglected the influence of the personal environment of the learners. It is possible that the learners have some experiences in daily life outside the learning area, which possibly influence their increase of social inclusion in addition to the contribution of the learning environment. Therefore the influence of elements as care, upbringing and work should be analysed in addition to the influence of the different elements of the learning area.

Thirdly, it is needed to analyse the results per generation. It would be interesting to analyse if the increase of social inclusion differ per sub-group and is 
different for older people than for youngsters in order to optimize the goal-setting of the different learning areas for each generation.

To sum up it seems to be the case that the intergenerational learning areas of the GUTS project stimulated the experienced increase in social inclusion of learners of both generations and that elements of the learning environment seem to influence this increase. More research is needed to explore the specific influence of these elements on both target groups older people and youngsters.

\section{References}

European Commission. (2010). Communication from the commission to the European Parliament, the Council, the European Economic and Social Committee and the Committee of the Regions: The European Platform against Poverty and Social Exclusion: A European framework for social and territorial cohesion. Brussels: European Commission.

Eurostat. (2014a). Europe 2020 indicators - poverty and social exclusion. Retrieved on March $8^{\text {th }} 2014$ from: <http://ec.europa.eu/eurostat/statistics-explained/index. php/Europe_2020_indicators_-_poverty_and_social_exclusion>.

Eurostat. (2014b). Statistics Explained: Unemployment statistics. Retrieved March $8^{\text {th }}$ 2014 from: <http://ec.europa.eu/eurostat/statistics-explained/index.php/Unemployment_statistics>.

Eurostat. (2014c). European Commission Eurostat Data Database, Population and social conditions, Demography Population projections. Retrieved March $8^{\text {th }} 2014$ from: $<$ http://ec.europa.eu/eurostat/tgm/table.do?tab=table\&init=1\&language=en\&pc ode $=$ tsdde $511 \&>$.

De Greef, M., Segers, M. \& Verté, D. (2010). Development of the SIT, an instrument to evaluate the transfer effects of adult education programs for social inclusion, Studies in Educational Evaluation (36), 42 - 61.

De Greef, M., Segers, M. \& Verté, D. (2012). Understanding the effects of training programs for vulnerable adults on social inclusion as part of continuing education. Studies in Continuing Education. DOI: 10.1080/0158037X.2012.664126.

Kumpulainen, K. (2010a). Social cohesion as intercultural dialogue. Lifelong Learning in Europe, vol. 15(1).

Kumpulainen, K. (2010b). Learning promotes wellbeing - Wellbeing promotes learning. Lifelong Learning in Europe, vol. 15(2).

Lupi, C., De Greef, M., Segers, M. \& Verté, D. (2011). Does adult education make a difference? The results of a survey in eight European countries. Maastricht: EDAM.

Verté, D. \& De Witte, N. (2015). Belgian Ageing Studies. 10 jaar onderzoek voor en door ouderen. Open University Press. 
Tinie $\mathrm{Kardol}^{5}$

Vrije univerzitet u Briselu, Belgija

Alina Vlădut ${ }^{6}$, Sorin Avrim ${ }^{7}$

Univerzitet u Krajovi, Rumunija

\section{Međugeneracijsko učenje: merenje učinka u pet zemalja ${ }^{8}$}

Apstrakt: Sa rizikom društvene izopštenosti suočava se $24.4 \%$ evropskog stanovništva. Po poslednjim ciframa, stepen društvene izopštenosti varira u zavisnosti od države i ciljne grupe. Na osnovu skorašnjih tendencija (kao što je porast nezaposlenosti kod mladih i sve starija populacija), izgleda da je neophodno, uz podršku mladima ka društvenoj inkluziji, takođe osigurati da veći broj starijih ljudi u Evropi budu aktivno uključeni u evropsko društvo. Iako je nekoliko studija pokazalo da obrazovanje može da utiče na stepen društvene inkluzije učenika, još uvek nedostaje dokaza o tome da li međugeneracijsko učenje kod mladih i starih osoba može da doprinese društvenoj inkluziji obe ove grupe. Višegeneracijsko obučavanje za društvenu inkluziju (u originalu: Generations Using Training for Social inclusion (GUTS)) je evropski projekat koji je merio učinak međugeneracijskog učenja na društvenu inkluziju. Jedan od glavnih ciljeva GUTS projekta bio je da iskombinuje ono što ide dobro mladima sa jedne, i starima, sa druge strane, tako da obe grupe mogu da uče jedna od druge i dobiju nova znanja i veštine kako bi se nosili sa svakodnevnim problemima u društvu. U skladu sa strategijom Evropa 2020, GUTS projekat je imao za cilj da umanji društvenu izopštenost kroz projekte međugeneracijskog učenja. Deset oblasti učenja je organizovano u pet zemalja, naime: Belgiji, Hrvatskoj, Nemačkoj, Letoniji, i Holandiji. Rezultati ukazuju da su oblasti međugeneracijskog učenja GUTS

\footnotetext{
${ }^{5}$ Dr Tinie Kardol je profesor na Vrije univerzitetu, Brisel, Belgija.

${ }^{6}$ Dr Alina Vlădut je predavačica na Fakultetu društvenih nauka, Univerzitetu u Krajovi, Rumunija.

${ }^{7}$ Sorin Avrim je asistentkinja na Fakultetu društvenih nauka, Univerzitetu u Krajovi, Rumunija.

${ }^{8}$ Članak je nastao kao rezultat rada grupe autora: Liesbeth De Donder, Vrije Universiteit Brussel; Radu Constantinescu, University of Craiova; Titela Vilceanu, University of Craiova; Dorien Brosens, Vrije Universiteit Brussel; Maurice De Greef, Vrije Universiteit Brussel; Daniela Grignoli, University of Molise; Margherita di Paolo, University of Molise; Regy van den Brand, Vughterstede Dis Kusters, Vughterstede; Dieter Zisenis, bbb Büro for berufliche Bildungsplanung R. Klein \& Partner GbR; Rosemarie Klein, bbb Büro for berufliche Bildungsplanung R. Klein \& Partner GbR; Anamarija Tkalcec, CESI Center for Education and Research; Sanja Cesar, CESI Center for Education and Research; Liesbeth Goossens, CVO Antwerpen; Koen Daenen, CVO Antwerpen; Ilze Buligina, Talakizglitibas biedriba; Biruta Sloka, University of Latvia; Petra Herre, Evangelisches Erwachsenenbildungswerk Nordrhein.

Rad predstavlja deo GUTS Projekta, sufinansiranog od strane Erazmus+ programa Evropske komisije. Data publikacija odražava isklučivo stavove autora i autorki i Komisija nije odgovorna za bilo koju upotrebu informacija sadržanih u tekstu.
} 
projekta stimulisala iskustveno uvećanje stepena društvene inkluzije među učenicima obe generacije, i da su elementi atmosfere u kojoj se učenje odvijalo izgleda zaslužni za ovo uvećanje. Dalje istraživanje je potrebno da se prouči tačni uticaj ovih elemenata na obe ciljne grupe: mlade i stare.

Ključne reči: međugeneracijsko učenje, aktivno starenje, društvena inkluzija, učinak učenja, evropske oblasti učenja. 